\title{
Enhanced feeding by pelagic juvenile myctophid fishes within a region of island-induced flow disturbance in the Coral Sea
}

\author{
David Rissik*, Iain M. Suthers \\ School of Biological Sciences, University of New South Wales, Sydney, New South Wales 2052, Australia
}

\begin{abstract}
The feeding success of post larvae and juveniles of 2 myctophid fishes (Diaphus kapalae and Myctophum sp.) was compared between the free stream and a flow-disturbed region in the lee of Cato Reef in the south Coral Sea using particle-size analysis. Both taxa fed more successfully in the disturbed region than in the free stream, where uplifting resulted in up to $50 \%$ greater concentrations of small (250 to $1000 \mu \mathrm{m}$ equivalent spherical diameter) prey items at depths between 30 and $70 \mathrm{~m}$ around the thermocline. Gut fullness in both taxa was significantly related to the concentrations of small-sized zooplankton (D. kapalae: $\mathrm{r}=0.63, \mathrm{p}<0.05$; Myctophum sp.: $\mathrm{r}=0.55, \mathrm{p}<0.05$ ). There were, however, differences in the sizes of food items consumed in the free stream and the disturbed region and between the 2 taxa of fishes studied. Non parametric multi-dimensional scaling analysis indicated that similarsized individuals of $D$. kapalae and Myctophum sp. within a region consumed a different particle-size community, probably enabling them to co-exist. The taxonomic composition of the diets of the 2 taxa reflected the available prey items around the island. In an oligotrophic environment such as the south Coral Sea, island-induced disturbance appeared to be an important contributor to the pelagic food web.
\end{abstract}

KEY WORDS: Particle size analysis · Island mass effect · Juvenile myctophids $\cdot$ Feeding success $\cdot$ Optical plankton counter

Resale or republication not permitted without written consent of the publisher

\section{INTRODUCTION}

Oceanographic flow disturbance downstream of isolated reefs results in increased primary and secondary production (Heywood et al. 1991), and increased concentrations of potential prey items for predators. Flow disturbance, where nutrients are uplifted into the euphotic zone by currents moving past islands or reefs, has been well documented near islands in both shallow and deep water in the south-western Coral Sea (Wolanski et al. 1984, 1996, Wolanski 1986, Coutis \& Middleton 1999). Doming of isotherms and increased nutrient, chlorophyll and zooplankton concentrations were present in the flow-disturbed zone immediately

*Present address: Estuary Management, Department of Land and Water Conservation, 10 Valentine St, Parramatta, New South Wales 2150, Australia.

E-mail: drissik@dlwc.nsw.gov.au north of Cato Reef (Suthers 1996, Rissik et al. 1997). Although previous studies on the island-mass effect have found increased primary and secondary production (manifest by greater zooplankton concentrations; Heywood et al. 1991), none have examined feeding success of a higher level predator in such systems.

These areas are important in the understanding of tropical ocean systems, especially in oligotrophic areas such as the south Coral Sea, where a substantial yellow-fin tuna fishery exists (Kailola et al. 1993). Over $300000 \mathrm{t}$ of yellow-fin tuna were caught in the western Pacific region in 1990 (South Pacific Commission 1991). The dominant prey item of yellow-fin and big eye tuna in the south Coral Sea is the myctophid Diaphus sp. (McPherson 1991), yet little is known about the feeding of myctophid juveniles in tropical Australian waters.

Myctophids generally feed at night, on a diet dominated by planktonic crustaceans, predominantly cope- 
pods (Woerner 1979, Hopkins \& Gartner 1992). Their diets have been reported to reflect the availability of prey in the environment (Kinzer 1977, Sameoto 1988). Myctophids are daily vertical migrators, moving from depths between 350 and $450 \mathrm{~m}$ to feed in the surfacewater layer (upper $100 \mathrm{~m}$ ) at night (Sameoto 1988). This results in many myctophid taxa occupying a similar habitat and feeding niche at night (Hopkins \& Gartner 1992). Consequently, the diets of many myctophid taxa show significant overlap (Tyler \& Pearcy 1975, Young \& Blaber 1986, Pakhomov et al. 1996). There is evidence, however, that myctophid taxa are able to coexist in a similar feeding niche by selecting differentsized prey, thereby preventing or reducing competition for the same food resources (Roe \& Badcock 1984, Sameoto 1988, Hopkins \& Gartner 1992).

Particle-size spectra have been used to simplify the taxonomic and trophic complexity of the pelagic zooplankton community and as a means of comparing plankton responses between systems which may otherwise have been confounded by the different taxonomic composition of these systems (Sheldon et al. 1977, Piontkovski et al. 1995). The changes in concentrations of various particle-size classes of zooplankton assemblages have been used to indicate responses of those assemblages to different environmental conditions and changes in the physical structure of water masses (Rodrieguez \& Mullin 1986, Sprules \& Munawar 1986, Rissik et al. 1997). The use of a size-based approach to assess nutritional responses of fish is particularly relevant in systems in which there are changes in the concentrations of different-sized organisms but not in taxonomic composition, such as around Cato Reef (Rissik et al. 1997).

In this paper we examine the feeding response of common pelagic planktivorous fishes to the changes in concentration of different zooplankton size-classes that occurred between the free stream and the flowdisturbed zone of Cato Reef, south-western Coral Sea. The aims of this study were to assess the significance of island-induced disturbance and associated uplifting on the feeding of 2 taxa of juvenile myctophids, and to use size-based techniques to compare the diets of 2 subtropical pelagic juvenile myctophid taxa.

\section{MATERIALS AND METHODS}

Sampling area. Cato Reef $\left(23^{\circ} \mathrm{S}, 150^{\circ} \mathrm{E}\right)$ is an isolated coral reef situated $\sim 375 \mathrm{~km}$ east of Rockhampton, Queensland, Australia, in the south-western Coral Sea (Fig. 1). The reef rises steeply from $2500 \mathrm{~m}$ deep to the surface over a distance of $\sim 50 \mathrm{~km}$. The $50 \mathrm{~m}$ isobath is elliptical, with approximately 10 by $15 \mathrm{~km}$ axes running EW and NS, respectively (Fig. 1). Two unvege-

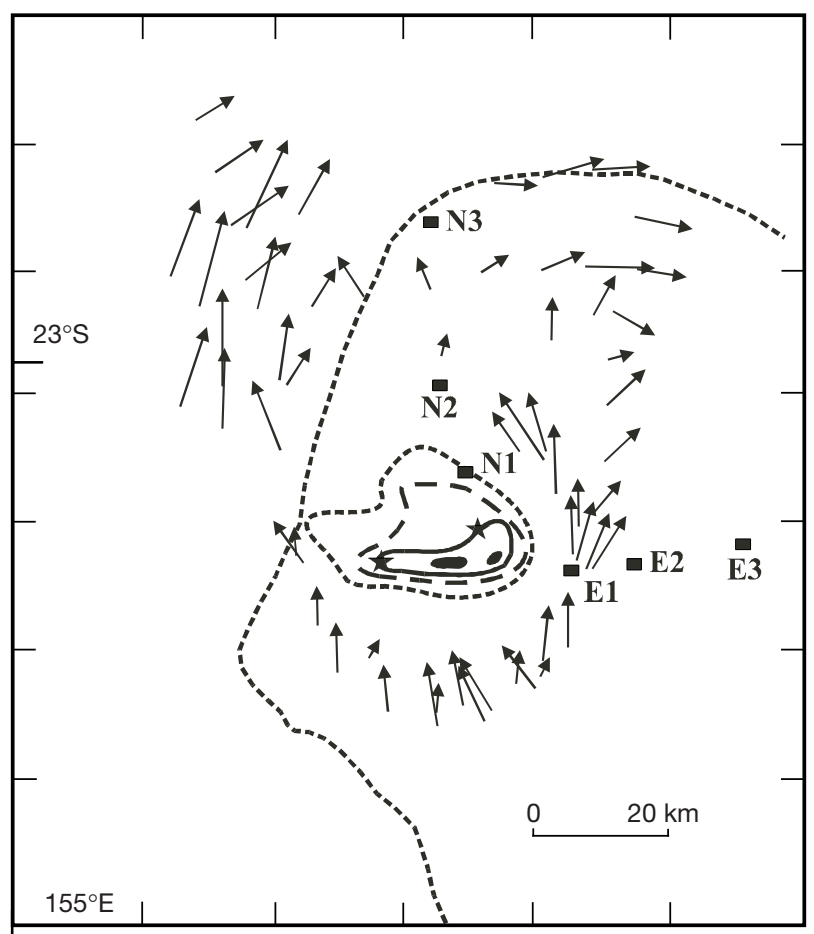

Fig. 1. Map of study area around Cato Reef showing direction and strength of water movement $\left(0.3 \mathrm{~m} \mathrm{~s}^{-1}\right.$ current) (arrows). Sampling stations are depicted by squares to the north and east of the island; the 50,500, 1000 and $2000 \mathrm{~m}$ depth contours are indicated. Stars: positions of 2 Aanderaa current meters deployed between October 1992 and February 1993 (adapted from Rissik et al. 1997)

tated sand cays are located on the reef, the larger of which is $\sim 600 \mathrm{~m}$ long. North of the sand cays is a lagoon with a mean depth of about $\sim 2 \mathrm{~m}$ (Fig. 1). Freshwater runoff from the island is insignificant.

Sampling procedure. During 16 to 21 February 1993, the Acoustic Doppler Current Profiler (ADCP) revealed a northward flow of approximately $30 \mathrm{~cm} \mathrm{~s}^{-1}$ (averaged over the 0 to $120 \mathrm{~m}$ depth range). This resulted in a region of flow disturbance extending $70 \mathrm{~km}$ north of the island (Coutis \& Middleton unpubl. data). Two transects of 3 fixed stations each were established (Fig. 1, Table 1): one perpendicular to the free-stream flow, east of the reef (E transect, Stns E1, E2 and E3) and the other downstream and through the wake region from south to north ( $\mathrm{N}$ transect, Stns N1, N2 and N3; Table 1, Fig. 1).

Each station was sampled at least once on each of 3 nights (Table 1) using $1 \mathrm{~m}^{2}$ opening and closing EZNET (Open Seas Instruments, Musquodoboit Harbour, Nova Scotia, Canada) multiple net/depth and neuston plankton samplers. At each station on each transect, plankton samples were collected within 3 depth strata: $15-45,45-75$ and 75-105 $\mathrm{m}$. The EZNET was fitted with three $330 \mu \mathrm{m}$ mesh nets, General 
Table 1. Description of stations and transects. Date (1993), Station code, latitude, longitude, bathymetry at each station and distance from $100 \mathrm{~m}$ isobath

\begin{tabular}{|lrccc|}
\hline Stn & $\begin{array}{r}\text { Latitude } \\
\left({ }^{\circ} \mathrm{S}\right)\end{array}$ & $\begin{array}{c}\text { Longitude } \\
\left({ }^{\circ} \mathrm{E}\right)\end{array}$ & $\begin{array}{c}\text { Bathymetry } \\
(\mathrm{m})\end{array}$ & $\begin{array}{c}\text { Distance } \\
(\mathrm{km})\end{array}$ \\
\hline Feb 16, 19, 21 & & & \\
E1 & 23.25 & 155.68 & 1057 & 6.2 \\
E2 & 23.23 & 155.77 & 1422 & 14.6 \\
E3 & 23.22 & 155.91 & 1810 & 29.3 \\
Feb 17, 18, 20 & & & \\
N1 & 23.15 & 155.55 & 294 & 3.4 \\
N2 & 23.03 & 155.53 & 1441 & 15.8 \\
N3 & 22.89 & 155.52 & 1744 & 37.7 \\
& & & & \\
\hline
\end{tabular}

Oceanics digital flow meters (internal and external), pitch and roll sensors, and a CTD. A $75 \times 75 \mathrm{~cm}$ neuston net fitted with $330 \mu \mathrm{m}$ mesh and a General Oceanics flow meter was deployed from the side of the vessel simultaneously with the EZNET. At the nominal tow speed of $2.5 \mathrm{knots}$, each EZNET net filtered $800 \mathrm{~m}^{3}$ and each neuston net $450 \mathrm{~m}^{3}$ during each $10 \mathrm{~min}$ towing period. After recovery, the contents of each codend were immediately preserved in $5 \%$ formalin and salt water before rinsing the net (to reduce the possibility of deterioration of samples in the $>25^{\circ} \mathrm{C}$ water temperature) and preserving the wash-down in a similar manner.

While steaming between stations, we deployed TUBSS (Towed Underwater Biological Sensing System; Taggart et al. 1996, Rissik et al. 1997) in an undulating (tow-yo) manner to collect temperature, and particle size/abundance data for approximately $20 \mathrm{~min}$. The optical plankton counter (OPC) counts and sizes the cross-sectional area of plankton particles (as equivalent spherical diameter, esd) which interrupt a coherent light beam $(4 \mathrm{~mm} \times 2 \mathrm{~cm})$ transiting a $2 \times 22 \mathrm{~cm}$ sampling tunnel to a photodiode receiver (Herman 1988, Sprules et al. 1992). The OPC is electronically designed to output particle sizes into digital bins expressed as a geometric exponential series between 1 and 4096 that correspond to sizes between $\sim 75$ and $\sim 9000 \mu \mathrm{m}$ esd. In practice, sensitivity and typically high particle concentrations limit the smallest reliable size to $\sim 250 \mu \mathrm{m}$ esd (near Digital Bin 7). Likewise, typically low particle concentrations limit the largest practical size to $\sim 2500 \mu \mathrm{m}$ esd (near Digital Bin 442). In our application, the OPC sampled the water at $5.7 \mathrm{l} \mathrm{s}^{-1}$ at the nominal towing speed of 2.5 knots $\left(1.3 \mathrm{~m} \mathrm{~s}^{-1}\right)$. The OPC also provided a measure of light attenuation in the light path that resulted from water colour and the concentration of particles below the $250 \mu \mathrm{m}$ esd sensitivity range (Herman 1988). The mean volume of water sampled by the OPC in a 20 min tow was approximately
$7 \mathrm{~m}^{3}$. The nominal transit time of $20 \mathrm{~min}$ between stations on each transect allowed between 2 and 4 complete undulations (down and up) of TUBSS between depths of $\sim 5$ and $\sim 120 \mathrm{~m}$ using a winch/wire speed sufficient to change sampling depth at a nominal rate of $0.5 \mathrm{~m} \mathrm{~s}^{-1}$.

Particles within the size range 250 to $2500 \mu \mathrm{m}$ dominated the plankton during the study period and gave an indication of the distribution and abundance of zooplankton species in the area (see Table 2). Nineteen geometric mean size classes were classified into 2 size groups; small (300 to $1000 \mu \mathrm{m}$ esd) and medium (1000 to $2500 \mu \mathrm{m}$ esd) particles (Rissik et al. 1997).

Laboratory and analysis. In the laboratory all larval and pelagic juvenile fish were removed from the samples (Suthers et al. unpubl. data), and the zooplankton stored in $2 \%$ formalin/freshwater. Fish were stored in $95 \%$ alcohol. Two species of pelagic juvenile myctophids captured at all depths and stations were used for gut analysis: Diaphus kapalae $(\mathrm{n}=154)$, and a single species of Myctophum sp. $(\mathrm{n}=211)$ which could not be identified further (Paxton pers. comm.). Fishes between 11 and $16 \mathrm{~mm}$ standard length (SL) were analysed to reduce the influence of ontogenetic diet shift. To reduce bias in the subjective measure of gut fullness, fish were placed in separate vials, with a coded system, so that the transect, station and depth of capture were not known during assessment.

The standard length of each fish was measured using an optical micrometer. Stomach contents were removed using electrolytically-sharpened tungsten needles and fine forceps. Gut contents were examined under a mixture of glycerine and chloryzol black $\mathrm{E}$, which stained the exoskeleton of crustaceans, aiding identification (Murdoch 1990). Gut contents were identified to the lowest possible taxon (Dakin \& Colefax 1940).

Gut fullness was estimated from the relative size of the alimentary canal and the amount of gut contents (Rissik \& Suthers 1996): The following criteria were used: (1) empty; (2) at least some gut contents; (3) gut half full; (4) greater than half full; (5) gut distended.

The length and width of each prey item were measured, enabling the area of each organism to be calculated. The area of each prey item was converted to an esd. Length measurements of copepods with missing abdomens were obtained by measuring the prosome width and obtaining lengths using prosome widthbody length regressions established for calanoid, and cyclopoid copepods present in the stomachs of fishes from this study (Rissik unpubl. data). Gut contents were generally intact and estimates of this nature were used for $<2 \%$ of the total gut contents examined.

Prey items were divided into 19 size classes between 250 and $2500 \mu \mathrm{m}$ esd, with approximately $120 \mu \mathrm{m}$ 
intervals for comparison with the 19 size classes recorded by the OPC.

Analysis. All data from the OPC were aggregated into $2 \mathrm{~s}$ sampling intervals (equivalent to a $1 \mathrm{~m}$ depth resolution and a $2.5 \mathrm{~m}$ horizontal resolution) and then smoothed using an 11 point running average. To facilitate comparison with the gut contents of the fishes, OPC data from each station were divided into 4 depth bins of $0-15,15-45,45-75$ and $75-105 \mathrm{~m}$, similar to the 4 plankton-net depth ranges. The mean number of small, medium and total (small + medium) particles and the mean attenuance were calculated for each sample.

To assess whether the 2 species selected differentsized prey than those present in the net samples, data indicating the abundance of each size class were used (from Rissik et al. 1997). The alpha index of selectivity (Chesson 1978), which standardises selectivity for the relative abundance of all prey types (sizes) was used.

The differences between the largest and smallest prey items consumed were used to assess the size range of the zooplankton particle-size spectrum consumed by each taxon.

Multi-dimensional scaling (MDS) was used to compare the zooplankton particle-size communities and the taxonomic communities consumed by each taxon at each depth within each station. MDS is an ordination technique which reduces a swarm of multivariate data (particle counts $\times$ stations/depth matrix) to fewer dimensions to identify patterns in the data structure. The stress value indicates the degree to which the data are distorted in order to fit the required dimensions. A stress value above 0.2 is unacceptable, and a value below 0.15 indicates a good fit (Clarke 1993). There are no values on the axes, as an MDS scatter can be arbitrarily rotated.

\section{RESULTS}

\section{Diets}

Diaphus kapalae consumed 27 taxa, dominated by copepods $(72.8 \%$ of all prey items). The copepod genera Oncaea contributed $29 \%$ of all particles consumed, Oithona 5\%, Acartia $11.3 \%$, Corycaeus $4.6 \%$ and Pleuromamma $13.3 \%$. The cladocerans Evadne and Penilia made up $10 \%$ of the prey items. Ostracods contributed to about $1 \%$ of the number of prey items (Table 2).

Myctophum sp. consumed 36 zooplankton taxa, also dominated in abundance by copepods (68.5\%). Of the 22 copepod taxa consumed, the cyclopoid genus Oncaea was the most dominant $(43.5 \%)$, with Pleuromamma (9.3\%) and Acartia (5.4\%) the only other cope-
Table 2. List of numerically dominant groups used to characterise size spectra indicated by the optical plankton counter. Size range is $\mu \mathrm{m}$ equivalent spherical diameter. Asterisks indicate particle size class into which the particles were divided (derived from Rissik et al. 1997)

\begin{tabular}{|c|c|c|c|}
\hline Taxa & Size range & Small & Medium \\
\hline Chaetognatha & $1249-1893$ & & * \\
\hline Bryozoa (larvae) & $425-535$ & ${ }^{*}$ & \\
\hline \multicolumn{4}{|l|}{ Crustacea } \\
\hline \multicolumn{4}{|l|}{ Copepoda } \\
\hline \multicolumn{4}{|l|}{ Calanoida } \\
\hline Rhincalanus & $883-1125$ & * & * \\
\hline Acartia & $535-1375$ & * & * \\
\hline Pleuromamma & $648-1761$ & * & * \\
\hline Candacia & $1003-2025$ & * & * \\
\hline \multicolumn{4}{|l|}{ Cyclopoida } \\
\hline Oithona & $480-610$ & * & \\
\hline Oncaea & $425-648$ & * & \\
\hline Corycella & $535-883$ & * & \\
\hline Copilia & $1083-1162$ & & * \\
\hline Ostracoda & $425-1003$ & * & \\
\hline \multicolumn{3}{|l|}{ Malacostraca, Amphi- } & * \\
\hline Mysidacea & $425-535$ & * & \\
\hline Mysidacea & $883-2566$ & & * \\
\hline Decapoda, Lucifer & $1631-2429$ & & * \\
\hline Cirripedia (larvae) & $425-535$ & * & \\
\hline Invertebrate eggs & $318-425$ & $*$ & \\
\hline \multicolumn{4}{|l|}{ Chordata } \\
\hline (fish eggs) & $535-883$ & * & \\
\hline (fish eggs) & $2025-2429$ & & * \\
\hline
\end{tabular}

pod genera contributing more than $2 \%$ of the diet component. Cladocerans (6\%), amphipods (3\%), ostracods $(3 \%)$ and invertebrate eggs $(5.4 \%)$ were the other major components (Table 3).

MDS and analysis of similarity (ANOSIM) found that the species composition of the diets of the 2 myctophids were similar $(\mathrm{p}=0.25)$.

\section{Gut fullness}

Both taxa from the flow-disturbed stations (N1, N2, N3) had fuller guts than those from fishes from the free stream (E1, E2, E3; Fig. 2). In particular, the mean gut fullness of myctophids captured at the 30 and $60 \mathrm{~m}$ depths at Stns N1 and N2 were significantly greater than of those captured at the surface or at $90 \mathrm{~m}$ at Stns N1 and N2, and more than at any depths at Stns N3 or at the 3 free-stream stations (E1, E2 and E3; Table 4).

Diaphus kapalae guts from the $60 \mathrm{~m}$ depth at Stns N1 (mean gut-fullness index, GFI = 3.7) and N2 (mean GFI $=4.1$ ) had fuller guts than those from other depths at Stns N1 and N2, and from all depths at the other 4 stations. 
Table 3. Mean number of each prey item consumed by Diaphus kapalae and Myctophum sp. around Cato Island. All stations and depths combined

\begin{tabular}{|c|c|c|c|c|}
\hline & Description & Genus & D. kapalae & Myctophum sp. \\
\hline \multicolumn{5}{|l|}{ Crustacea } \\
\hline Branchiopoda & & Evadne & 9.76 & 5.77 \\
\hline Ostracoda & & & 1.35 & 2.77 \\
\hline \multicolumn{5}{|l|}{ Copepoda } \\
\hline \multirow[t]{10}{*}{ Calanoida } & & Pleuromamma & 13.33 & 9.31 \\
\hline & & Undinula & 0 & 0.18 \\
\hline & & Centropages & 0 & 0.31 \\
\hline & & Lucicutia & 0 & 0.49 \\
\hline & & Temora & 3.47 & 3.93 \\
\hline & & Paracalanus & 0.45 & 0.62 \\
\hline & & Rhincalanus & 0.36 & 0.12 \\
\hline & & Labidocera & 0 & 0.12 \\
\hline & & Candacia & 1.37 & 0.38 \\
\hline & & Acartia & 11.32 & 5.44 \\
\hline \multirow[t]{4}{*}{ Harpacticoida } & & Sulcanus & 0.29 & 0 \\
\hline & & Tigriopus & 0 & 0.36 \\
\hline & & Candena & 0 & 0.15 \\
\hline & & Microsetella & 0.65 & 1.13 \\
\hline \multirow[t]{5}{*}{ Cyclopoida } & & Sapphirina & 1.56 & 0.70 \\
\hline & & Corycella & 1.22 & 0.81 \\
\hline & & Corycoeus & 4.62 & 1.11 \\
\hline & & Oithona & 4.97 & 1.78 \\
\hline & & Oncaea & 28.80 & 43.49 \\
\hline \multirow[t]{3}{*}{ Siphonostomatoida } & & Caligus & 0 & 0.10 \\
\hline & Copepodite & & 0.10 & 0.33 \\
\hline & Nauplii & & 0.87 & 1.27 \\
\hline Cirripedia & Nauplii & & 2.01 & 0.34 \\
\hline \multicolumn{5}{|l|}{ Malacostraca } \\
\hline Mysidacea & & & 1.22 & 2.89 \\
\hline \multirow[t]{2}{*}{ Amphipoda } & Other & & 1.32 & 2.84 \\
\hline & & Brachyscelus & 0 & 0.35 \\
\hline \multirow[t]{2}{*}{ Decapoda } & Zoaea & & 0.29 & 0.12 \\
\hline & Unidentified & & 4.75 & 4.54 \\
\hline \multicolumn{5}{|l|}{ Mollusca } \\
\hline Gastropoda & & & 2.48 & 1.07 \\
\hline \multirow{2}{*}{ Bivalvia } & Unidentified & & 0.21 & 0.33 \\
\hline & Pelycopoda & & 0 & 0.14 \\
\hline \multicolumn{5}{|l|}{ Annelida } \\
\hline Polychaeta & & & 0.21 & 0.09 \\
\hline \multicolumn{5}{|l|}{ Bryozoa } \\
\hline Anasca & & Membranipora & 0 & 0.76 \\
\hline \multirow[t]{2}{*}{ Chaetognatha } & & Sagitta & 0.68 & 0.86 \\
\hline & $\begin{array}{l}\text { Invertebrate } \\
\text { eggs }\end{array}$ & & 2.33 & 5.34 \\
\hline
\end{tabular}

Myctophum sp. also fed significantly more successfully in the disturbed transect than in the free stream, especially at the 30 and $60 \mathrm{~m}$ depth bins (Table 4, Fig. 2b). Guts from fish captured at all stations were generally most full at the 30 and $60 \mathrm{~m}$ depths. Exceptions were for the $30 \mathrm{~m}$ depth at Stn E1, in which the fish had empty guts (mean GFI = 1.8), and at the $90 \mathrm{~m}$ depth at Stn N3, which had a GFI of 3.2. In general, guts were least full at the $90 \mathrm{~m}$ and most full at the 30 and $60 \mathrm{~m}$ depths.

The number of prey items per fish was not significantly related to fish length. Fishes with greater levels of gut fullness had more items in their stomachs (Diaphus kapalae, $\mathrm{r}=0.54$, $\mathrm{p}<0.05 ;$ Myctophum sp., $\mathrm{r}=0.57, \mathrm{p}<$ 0.05 ; Fig. 3), with variation in the relationships arising from variability in the sizes of prey items consumed. Individuals may have had full guts after consuming a single large prey item such as a mysid larva, or may have had a half-full gut after consuming many small prey items such as the cyclopoid copepods Oncaea spp.

More than $90 \%$ of the gut contents were between 250 and $1000 \mu \mathrm{m}$ esd in size (Fig. 4), i.e. in the small-particle category. Gut fullness was significantly related to average abundance of small particles within each depth bin at each station for Diaphus kapalae $(\mathrm{r}=0.63, \mathrm{n}=24, \mathrm{p}<0.05$; Fig. 5a) and for Myctophum sp. ( $\mathrm{r}=0.57, \mathrm{n}=24, \mathrm{p}<$ 0.05 ; Fig. $5 b$ ). Gut fullness was not related to particles in the medium-size range (1000 to $2500 \mu \mathrm{m}$ esd, $\mathrm{r}=0.24$ ).

Analysis of data from fishes that consumed items falling into more than 1 size class indicated that the standard lengths of each taxon were significantly related to the range of prey sizes consumed (Diaphus kapalae, $\mathrm{r}=0.90, \mathrm{n}=$ 25, $\mathrm{p}<0.05$; Myctophum sp., $\mathrm{r}=0.91$, $\mathrm{n}=21, \mathrm{p}<0.05 ;$ Fig. 6 ). The range of prey particles consumed increased as the length of the fishes increased. The size of the smallest particles consumed by both taxa did not increase with increased fish length, but larger fish simply consumed larger prey as well. There was no difference in the range of prey sizes consumed by either taxon in the free stream and the disturbed area.

\section{Size selectivity}

The majority of prey items consumed by the 2 myctophid taxa were between 250 and $2500 \mu \mathrm{m}$ esd. Diaphus kapalae ate particles between 250 and $1300 \mu \mathrm{m}$ esd, and did not consume larger items from the medium-size class (1300 to $2500 \mu \mathrm{m}$ esd), selecting strongly towards the small-size-class particles. Fish showed similar selectivity towards specific size classes at both free-stream and disturbed transects, with fish from the disturbed transect selecting for larger items than fish from the free stream (Fig. 7a,b). 

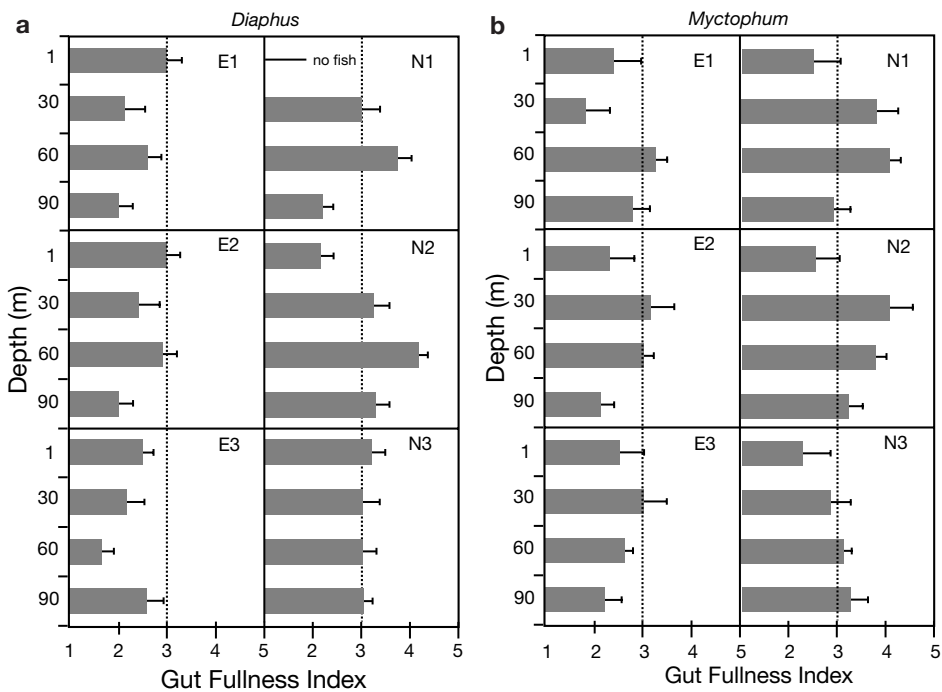

Fig. 2. (a) Diaphus kapalae and (b) Myctophum sp. Mean gut-fullness index (GFI) at each sampling depth and station around Cato Reef. Error bars are standard error. Dotted line at GFI 3 is for ease of comparison difference between the particle size assemblage of the gut contents of both taxa from Stns N2 and E2 (Fig. 8, $F=0.15, \mathrm{p}<0.01$ ).

\section{DISCUSSION}

\section{Feeding in the flow-disturbed region}

The myctophids Diaphus kapalae and Myctophum sp. had fuller guts around the thermocline, at 30 and $60 \mathrm{~m}$ depth at Stns N1 and N2 of the flow disturbed region, than at any depths within the 3 free-stream stations (E1, E2 and E3) and within Stn N3. Gut fullness of both taxa at Stn N3 was less than at Stns N1 and N2, but greater than at the 3 free-stream stations. Although nominally within the disturbed region, Stn N3 did not show the physical effects of disturbance, and the availability of zooplankton (potential prey items) within this station was similar to that in the free stream (Rissik et al. 1997, Coutis \& Middleton 1999). Suthers (1996), however, reported that $D$. kapalae captured in the disturbed zone during the same cruise as this study were in better condition and showed faster recent growth than fish from the free stream. The greater gut fullness and the better condition of these fish suggests that Stn N3 of the disturbed region provided a better source of nutrition than the free-stream stations over the previous few days.

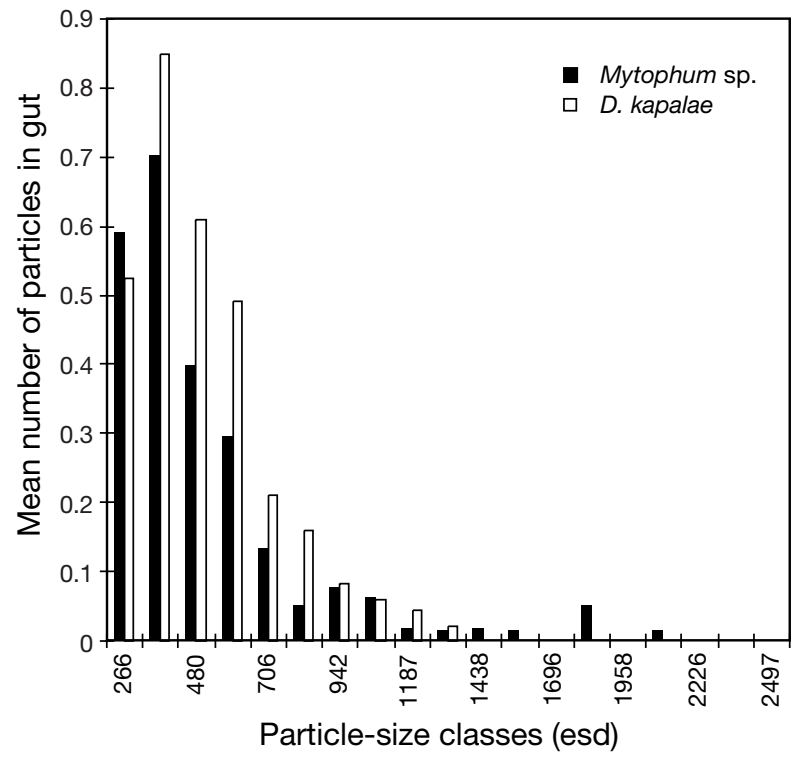

Fig. 4. Diaphus kapalae and Myctophum sp. Mean number of each particle-size class consumed at each depth, station and transect combined. esd: equivalent spherical diameter
Fig. 3. Diaphus kapalae (o) and Myctophum sp. (•). Relationship between average gut fullness and average number of items in stomachs at all depths within all stations (combined data)

Myctophum sp. did not consume prey items larger $2025 \mu \mathrm{m}$ esd. Although most of the gut conten these fish did not consume these prey size classes in and $1500 \mu \mathrm{m}$ esd at Stn N2 (Fig. 7c,d).

Comparison of the particle size structure of the gut contents of the 2 myctophid taxa using MDS and ANOSIM indicated that despite the differences in prey selection between the 2 myctophid taxa, there was no significant difference between the particle size communities consumed by Diaphus kapalae and Myctophum sp. ( $\mathrm{p}>0.05)$. There was, however, a significant

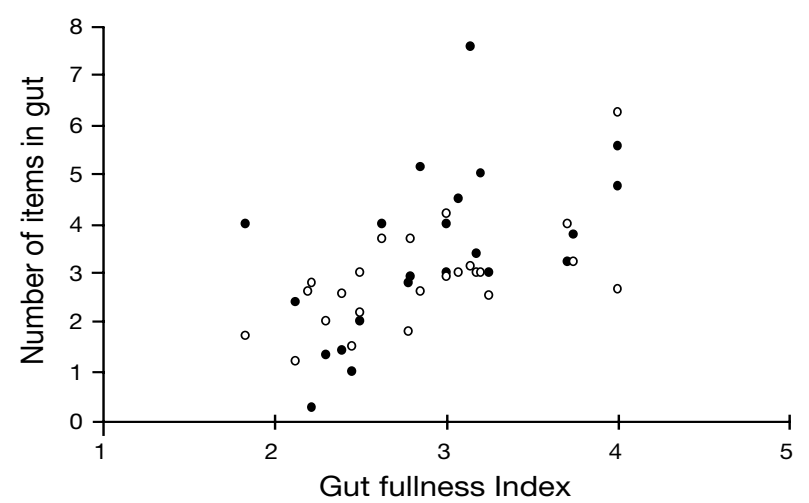


Table 4. Diaphus kapalae and Myctophum sp. ANOVA comparing gut fullness between transects (TRT), station (STN) and depth (DPH). ${ }^{*}$ Significant difference

\begin{tabular}{|lrrrrl|}
\hline Source & SS & df & MS & $F$ & $p$ \\
\hline D. kapalae & & & & & \\
TRT & 12.9 & 1 & 12.9 & 13.0 & $0.00^{*}$ \\
STN & 2.1 & 2 & 1.0 & 1.0 & 0.4 \\
TRT $\times$ STN & 0.8 & 2 & 0.4 & 0.4 & 0.7 \\
DPH & 29.2 & 18 & 1.6 & 1.6 & 0.06 \\
Error & 129.95 & 151 & 1.0 & & \\
Myctophum & sp. & & & & \\
TRT & 14.2 & 1 & 14.2 & 5.3 & $0.03^{*}$ \\
STN & 3.2 & 2 & 1.6 & 0.6 & 0.6 \\
TRT $\times$ STN & 2.3 & 2 & 1.2 & 0.4 & 0.7 \\
DPH & 48.4 & 18 & 2.7 & 1.9 & 0.01 \\
Error & 258.5 & 191 & 1.4 & & \\
& & & & & \\
\hline
\end{tabular}

Each taxon consumed a different particle-size community in the free stream and the flow-disturbed zone, with each taxon consuming a greater abundance of small particles in the disturbed region. The availability of particles of this size fraction was greater in the disturbed region due to the concentrating effect of

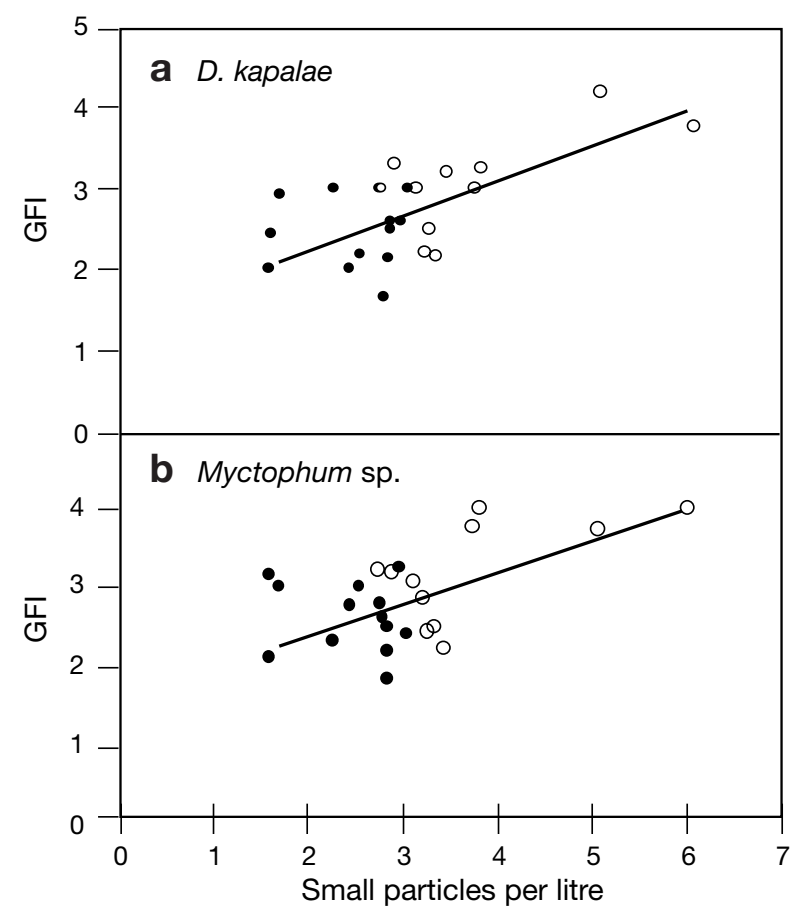

Fig. 5. (a) Diaphus kapalae and (b) Myctophum sp. Relationship between GFI and concentration of small particles (300 to $1000 \mu \mathrm{m}$ esd, as measured by optical plankton counter) at all depths within all stations (combined data). (o) Results from stations in flow-disturbed region, $(\bullet)$ results from free stream flow disturbance or increased production (Rissik et al. 1997). Concentrations of the small particles (which included the cyclopoid copepods Oncaea spp. and Oithona spp. and the copepodite stages of the calanoid copepods Acartia spp. and Pleuromamma spp.) were twice as high in the disturbed region as in the undisturbed region (Rissik et al. 1997). Each taxon also selected slightly larger prey items in the disturbed area, probably because of their greater availability and the benefits of eating larger prey (Uotani et al. 1978).

Flow-disturbed regions in deep island wakes are therefore likely to be present for long periods and probably result in greater concentrations of phytoplankton and zooplankton and enhance the feeding of larvae and pelagic juvenile fishes. The disturbed area in the lee of Cato Reef resulted from an average flow of $30 \mathrm{~cm} \mathrm{~s}^{-1}$. Two current meters deployed at Cato Reef between October 1992 and February 1993 (Fig. 1) showed that current speeds of $\geq 30 \mathrm{~cm} \mathrm{~s}^{-1}$ occurred regularly ( $55 \%$ of the time) around Cato Reef.

Recurrent oceanographic features such as island wakes or bank-associated gyres may often result in increased plankton abundance and thereby provide favourable feeding conditions for pelagic larvae and juvenile fishes in these areas. Many studies have showed a strong relationship between concentrations of young fishes and zooplankton in areas with particular oceanographic features such as estuarine plume fronts (Kingsford \& Suthers 1994), current-driven eddies and island wakes (Hamner \& Haurie 1981, Kingsford

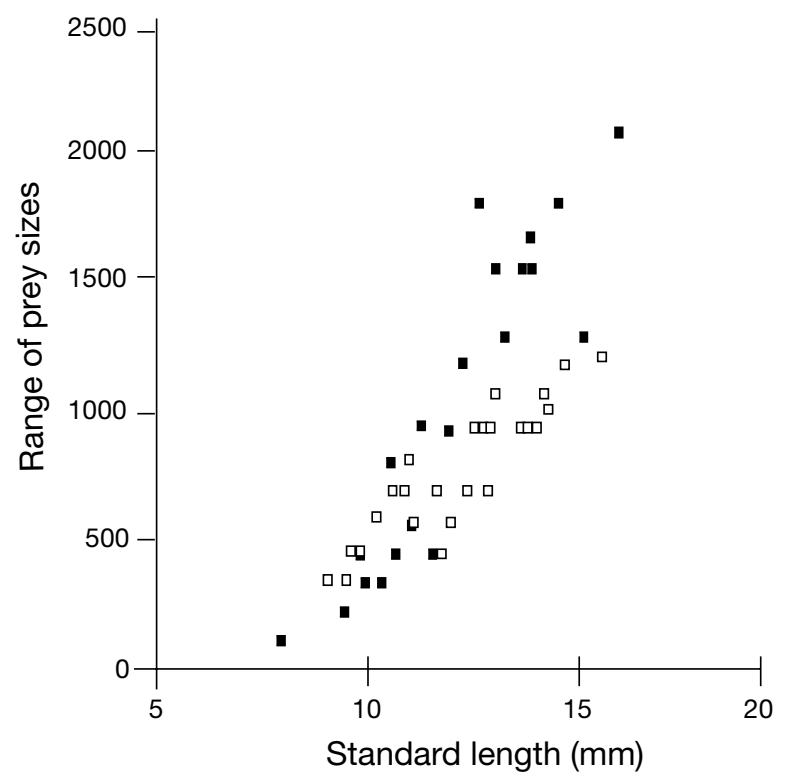

Fig. 6. Diaphus kapalae () and Myctophum sp. (ロ). Relationship between standard length of fish and range of size of prey items consumed 


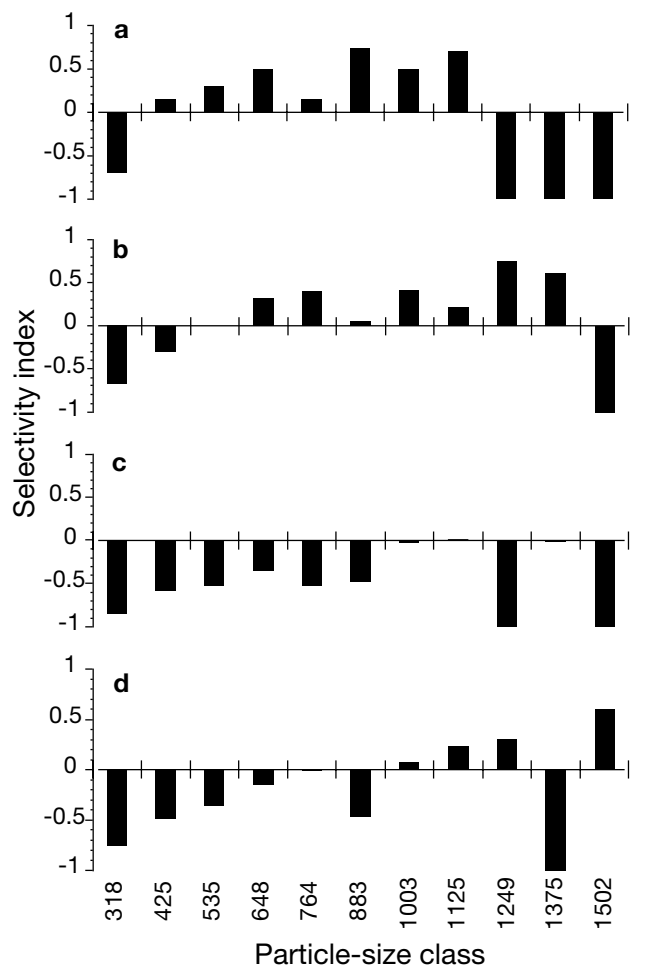

Fig. 7. Diaphus kapalae and Myctophum sp. Alpha selectivity index comparing abundance of prey items (11 particle-size classes) consumed by (a) D. kapalae at Stn E2, (b) D. kapalae at Stn N2, (c) Myctophum sp. at Stn E2 and (d) Myctophum sp. at Stn N2, with abundance of same 11 particle-size classes in environment at that station (data from optical planktonic counter)

1990). Few, however, have assessed the nutritional significance of these features by considering feeding success or by comparing gut contents with the availability of prey in and about the oceanographic feature. Atlantic cod larvae fed more successfully on increased zooplankton concentration which occurred in a retention zone on Sable Island Bank (McLaren \& Avendano 1995). Gut fullness (feeding success) of fish larvae in and about an estuarine plume front off eastern Australia was species-specific. Some taxa fed more effectively in the plume and front than in the ocean, while others fed with equal success in each of the 3 water masses (Rissik \& Suthers 1996). In the presence of a tidal front in the eastern North Sea, growth rates of larval sprat Sprattus sprattus were higher than in surrounding waters (Munk 1993). In the strong frontal boundary of a productive upwelled-water mass off California, adult tuna fed on the greater abundance of anchovies and pelagic crabs which occurred there (Fiedler \& Bernard 1987).

The results of this research and those from Rissik et al. (1997) highlight the trophic importance of island-

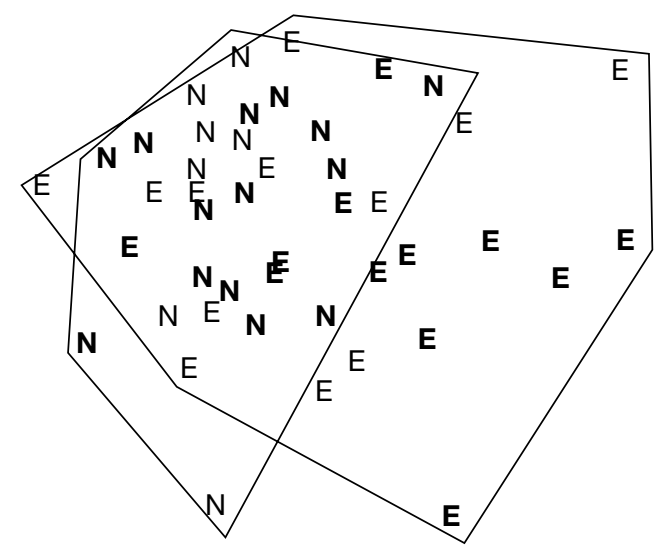

Fig. 8. Diaphus kapalae (bold print) and Myctophum sp. (normal print). Multi-dimensional scaling analysis comparing particle-size community consumed by $D$. kapalae and $M y c-$ tophum sp. Stress $=0.21$. Analysis of similarity indicated that significantly different particle-size communities were consumed at $\mathrm{E}$ and $\mathrm{N}$ stations $(F=0.15, \mathrm{p}<0.01)$

induced disturbance, in which upwelled nutrients promoted primary and secondary production and increased sustenance to planktivores in the island wake.

There was no difference between the taxonomic composition of the zooplankton consumed by either myctophid species in the free stream and the disturbed zone. This was probably a result of the similar taxonomic composition of zooplankton in the 2 areas, supporting the observations of other studies that myctophids are opportunistic feeders and that the taxonomic composition of their diets reflect the availability of prey taxa in the environment (Kinzer 1978, Sameoto 1988). This is also supported by the differences between the particle-size classes consumed in the wake and the free stream.

There were no differences in the range of prey sizes consumed by fishes in the free stream and the disturbed region. Fishes ate similar concentrations of larger particles and more smaller particles in the disturbed region because many of the smaller particlesize classes were twice as abundant in the disturbed region than in the free stream and large particles occurred in similar concentrations.

Increased phytoplankton and zooplankton concentrations have been reported to occur around islands as a result of nutrient enhancement caused by runoff and lagoon drainage (Dandonneau \& Charpy 1985, Le Borgne et al. 1985, Perrissinotto \& Duncome Rae 1990), wind-induced upwelling (Hernandez-Leon 1991), and stirring of ambient flow by deep, steep-sided, lowrelief islands (Heywood et al. 1990, Rissik et al. 1997).

In the oligotrophic south Coral Sea, any oceanographic features or regular oceanographic events which enhance nutrients and increase primary and secondary 
production, or which increase the concentration of potential prey items, should be of great ecological and nutritional significance to higher-level predators/consumers. Myctophids in the Coral Sea (particularly Diaphus species) are an important food source for yellowfin and big eye tuna (McPherson 1991). Flow-disturbed regions downstream of isolated reefs may be a significant factor influencing the substantial yellow-fin tuna fishery in the western Pacific region (>300000 $t$ in 1990; South Pacific Commission 1991).

\section{Feeding niche of co-existing myctophids}

Taxonomically, the diets of the 2 myctophid taxa overlapped considerably. Diaphus kapalae consumed 28 prey taxa, of which 27 were in common with the 36 zooplankton taxa consumed by Myctophum sp. There were, however, large differences between the proportions of the various prey items in the diets of the 2 taxa, and ANOSIM indicated that the diets were almost significantly different $(p=0.06)$. The sizes of the various prey items consumed by the 2 taxa varied considerably. D. kapalae strongly selected prey items between 300 and $1000 \mu \mathrm{m}$ esd and avoided particles smaller or larger than this. Myctophum sp. selected larger prey items despite consuming a wider range of prey sizes. Selectivity towards different taxa and towards prey of different sizes prevents competition for resources by fish taxa which feed in the same environment. Dietary overlap of prey species, but not of prey sizes, has been reported amongst many myctophid taxa which feed in the same environment (Tyler \& Pearcy 1975, Young \& Blaber 1986, Hopkins \& Gartner 1992). It has been suggested that size-specific predatory fishes which only consume large-sized prey items would be competitively disadvantaged compared to size-generalised predators if concentrations of large zooplankton were reduced and small zooplankton increased (Uotani et al. 1978). It is unlikely that the increase in small particles would have reduced the feeding success of either of the fishes in this study, since although concentrations of small particles increased significantly in the wake zone, this was not associated with a decline of the large zooplankton (Rissik et al. 1997).

Mouth width has been suggested to be the factor limiting the range of prey items consumed by predatory fishes (Hunter 1981, Gleason \& Bengtson 1996). This is reflected in the fishes in this study, where the wider-mouthed Myctophum sp. consumed a wider range of prey items than Diaphus kapalae. Size selectivity has been reported to occur in other species of myctophids (Roe \& Badcock 1984, Sameoto 1988, Hopkins \& Gartner 1992), between other taxa in laboratory and field conditions (Gleason \& Bengtson 1996). Mean prey size has been reported to increase with increased size of larvae of other taxa, with the minimum sizes of prey remaining relatively constant (Gadomski \& Boehlert 1984).

Of interest is the selectivity by Myctophum sp. towards the cyclopoid copepods Oncaea sp. These small copepods contributed to $29 \%$ of the diet of Diaphus kapalae and $43 \%$ of the diet of Mytophum sp. Oncaea spp. have been found to be a dominant item in the diets of other myctophids (Diaphus spp. and Gymnoscolepus spp.; Pakhomov et al. 1996). Although Oncaea spp. were common in the zooplankton, they did not contribute to more than $20 \%$ of the prey items, and their abundance in the gut contents of both taxa suggests strong selectivity towards them. This may reflect their swimming speed, visibility or escape responses.

In this study we assumed that the fishes did not regurgitate food during capture. The minimum size of fishes in this study was $11 \mathrm{~mm}$ SL. Myctophids of this size have coiled guts, and thus were unlikely to have regurgitated during capture, as opposed to fish with straight guts, such as clupeids, which regurgitate their food during capture (Arthur 1976).

We also assumed that there were no differences between particle sizes of zooplankton measured using the OPC and image analysis. The use of image analysis to identify size fractions has been discussed by Rissik et al. (1997), and the comparisons between zooplanktonic particle sizes measured by both OPC and image analysis made by Suthers et al. (unpubl. data) indicate a close correlation between results.

\section{Conclusions}

Myctophids have been reported to undergo diel vertical migration and migrate from depths $>300 \mathrm{~m}$ during the day to the surface to feed at night. The 2 myctophid taxa considered in this study, however, fed more successfully near the thermocline than in the surface waters or at depths $>75 \mathrm{~m}$. This is probably an opportunistic feeding response to the greater concentrations of potential food items available at these depths.

Most myctophid dietary studies have considered individuals of a wide range of sizes, and have been directed towards analysing and classifying the diets of these fishes in relation to the availability of prey items in the environment, or towards explaining the ability of many myctophid taxa to occupy a similar feeding niche. We, however, used fishes of a limited range of sizes (8 to $16 \mathrm{~mm} \mathrm{SL}$ ) as a tool to assess the nutritional significance of disturbance in the lee of an isolated island in the oligotrophic Coral Sea. 
Myctophids captured about the thermocline in the flow-disturbed area north of Cato reef fed more successfully than those from other locations about the reef. This is a direct response to the increased abundance of small prey items which were available at these depths due to increased secondary production. In an oligotrophic environment such as the south Coral Sea, the island-mass effect is an important mechanism enhancing the abundance of prey items and the feeding and health of myctophid fishes.

Acknowledgements. We thank our colleagues Chris Taggart and Jason Middleton for their valuable assistance. The master and crew of the RV 'Franklin' are gratefully acknowledged. John Paxton assisted with the myctophid identification. Jeff Leis and 3 anonymous reviewers commented on the manuscript. This study was supported by the Australian Research Council, Department of Industry, Technolgy and Commerce, Australian Geograpic.

\section{LITERATURE CITED}

Arthur AK (1976) Food and feeding of three fishes occurring in the Californian Current, Sardinops sagax, Engraulis mordax and Trachurus symmetricus. Fish Bull US 74: $517-530$

Chesson J (1978) Measuring preference in selective predation. Ecology 59:211-215

Clarke KR (1993) Non-parametric multivariate analyses of changes in community structure. Aust J Ecol 18:117-143

Coutis PF, Middleton JH (1999) Flow topography interaction in the vicinity of an isolated, deep ocean island. Deep-Sea Res 46:1633-1652

Dakin WJ, Colefax AN (1940) The plankton of Australian coastal waters off New South Wales. Australasian Medical Publishing Company Ltd, Glebe

Dandonneau Y, Charpy L (1985) An empirical approach to the island mass effect in the south tropical Pacific based on sea surface chlorophyll concentrations. Deep-Sea Res 32: 707-721

Fiedler PC, Bernard HJ (1987) Tuna aggregation and feeding near fronts observed in satellite imagery. Cont Shelf Res 7: 871-881

Gadomski DM, Boehlert GW (1984) Feeding ecology of pelagic larvae of English sole Parophrys vetulus and butter sole Isopsetta isolepis off the Oregon coast. Mar Ecol Prog Ser 199:165-177

Gleason TR, Bengtson DA (1996) Growth survival and size selective predation mortality of larval and juvenile inland silversides, Menidia beryllina (Pisces; Atherinidae). J Exp Mar Biol Ecol 199:165-177

Hamner WN, Haurie IR (1981) Effect of the island mass: waterflow and plankton pattern around a reef in the Great Barrier Reef Lagoon. Limnol Oceanogr 26:1084-1102

Herman AW (1988) Simultaneous measurement of zooplankton and light attenuance with a new optical plankton counter. Cont Shelf Res 8:205-221

Hernandez-Leon S (1991) Accumulation of mesozooplankton in a wake area as a causative mechanism of the 'island mass effect'. Mar Biol 109:141-147

Heywood KJ, Barton ED, Simpson JH (1990) The effects of flow disturbance by an oceanic island. J Mar Res 48:55-73

Heywood KJ, Scrope-Howe S, Barton ED (1991) Estimation of zooplankton abundance from shipborne ADCP backscatter. Deep-Sea Res 38:677-691

Hopkins TL, Gartner JV (1992) Resource-partitioning and predation impact of a low-latitude myctophid community. Mar Biol 114:185-197

Hunter JR (1981) Feeding ecology/predation. In: Lasker R (ed) Marine fish larvae: morphology, ecology and relation to fisheries. University of Washington Sea Grant Program, University of Washington Press, Seattle, p 34-77

Kailola PJ, Williams HJ, Stewart PC, Reichelt RE, McNee A, Grieve C (1993) Australian fisheries resources. Bureau of Natural Resource Sciences, Canberra

Kingsford MJ (1990) Linear oceanographic features: a focus for research on recruitment processes. Aust J Ecol 15: 391-401

Kingsford MJ, Suthers IM (1994) Dynamic estuarine plumes and fronts: importance to small fish and plankton in coastal waters of NSW, Australia. Cont Shelf Res 14: $665-672$

Kinzer J (1977) Observations on feeding habits of the mesopelagic fish Benthosema glaciale (Myctophidae) off NW Africa. In: Anderson WR, Zahurance BJ (eds) Oceanic sound scattering prediction. Plenum Press, New York, p 381-392

Le Borgne R, Dandonneau Y, Lemasson L (1985) The problem of the island mass effect on chlorophyll and zooplankton standing crops around Mare (Loyalty Islands) and New Caledonia. Bull Mar Sci 37:450-459

McLaren IA, Avendano P (1995) Prey field and diet of larval cod on Western Bank, Scotian Shelf. Can J Fish Aquat Sci 52:448-463

McPherson GR (1991) A possible mechanism for the aggregation of yellowfin and bigeye tuna in the north-western Coral Sea. Inf Ser Qd Dep Prim Inds Q191013:1-11

Munk P (1993) Differential growth of larval sprat Sprattus sprattus across a tidal front in the eastern North Sea. Mar Ecol Prog Ser 99:17-27

Murdoch RC (1990) Diet of hoki larvae (Macruronus novaezelandiae) off Westland, New Zealand. NZ J Mar Freshw Res 24:519-527

Pakhomov EA, Perissinotto R, McQuaid CD (1996) Prey composition and daily rations of myctophid fishes in the Southern Ocean. Mar Ecol Prog Ser 134:1-14

Perissinotto R, Duncombe Rae CM (1990) Occurrence of anticyclonic eddies on the Prince Edward Plateau (Southern Ocean): effects on phytoplankton biomass and production, Deep-Sea Res 37:777-793

Piontkovski SA, Williams R, Melnik TA (1995) Spatial heterogeneity, biomass and size structure of plankton of the Indian Ocean: some general trends. Mar Ecol Prog Ser 117:219-227

Rissik D, Suthers IM (1996) Feeding in a larval fish assemblage: the nutritional significance of an estuarine plume front. Mar Biol 125:233-240

Rissik D, Suthers IM, Taggart CT (1997) Enhanced zooplankton abundance in the lee of an isolated reef in the south Coral Sea: the role of flow disturbance. J Plankton Res 19: 1347-1368

Rodriguez J, Mullin MM (1986) Relation between biomass and body weight of plankton in a steady state oceanic ecosystem. Limnol Oceanogr 31:361-370

Roe HSJ, Badcock J (1984) The diel migrations and distributions within a mesopelagic community in the North East Atlantic. Prog Oceanogr 13:389-424

Sameoto DD (1988) Feeding of lantern fish Benthosema glaciale off the Nova Scotia shelf. Mar Ecol Prog Ser 44: $113-129$ 
Sheldon RW, Suttcliffe WH, Parangape MA (1977) Structure of pelagic food chain and relationship between plankton and fish production. J Fish Res Board Can 34:2344-2353

South Pacific Commission (1991) Status of tuna fisheries in the SPC area during 1990, with annual catches since 1952. Fourth Standing Committee on Tuna and Billfish, Port Vila, Vanuatu, 17-19 June 1991. Working paper No. 3. South Pacific Commission, Noumea, p 1-75

Sprules WG, Munawar M (1986) Plankton size spectra in relation to ecosystem productivity, size, and pertubation. Can J Fish Aquat Sci 43:1789-1794

Sprules WG, Bergstrom B, Cyr H, Hargreaves BR, Kilham SS, MacIsaac K, Matsushita K, Stemberger RS, Williams R (1992) Non-video optical instruments for studying zooplankton distribution and abundance. Arch Hydrobiol Beih Ergeb Limnol 36:45-58

Suthers IM (1996) Spatial variability of recent otolith growth and RNA indices in pelagic juvenile Diaphus kapalae (Myctophidae): an effect of flow disturbance near an island? Mar Freshw Res 47:273-282

Taggart CT, Thompson KR, Maillet GL, Lochmann SE, Griffin DA (1996) Abundance distribution of larval cod (Gadus morhua) and zooplankton in a gyre-like water mass on the Scotian Shelf. In: Watanabe Y, Yamashita Y, Oozeki Y

Editorial responsibility: Otto Kinne (Editor),

Oldendorf/Luhe, Germany (eds) Survival strategies in early life stages of marine resources. AA Balkema, Rotterdam, p 155-173

Tyler HR Jr, Pearcy WG (1975) The feeding habits of three species of lantern fishes (family Myctophidae) off Oregon, USA. Mar Biol 32:7-11

Uotani I, Izuha A, Asai K (1978) Food habits and selective feeding of anchovy larvae (Engraulis japonica). Bull Jpn Soc Sci Fish 44:427-434

Woerner (1979) Nutritional biology of three myctophid species, Benthosema glaciale (Reinhardt, 1837), Ceratoscopelus maderensis (Lowe, 1839) and Myctophum (M.) punctatum Rafinesque, 1810, from the North West African upwelling region. Meteor ForschErgebn (Reihe D: Biol) 30:41-61

Wolanski E (1986) Island wakes and internal tides in stratified shelf waters. Ann Geophys 4:425-440

Wolanski E, Imberger J, Heron ML (1984) Island wakes in shallow coastal waters. J Geophys Res 89:10553-10569

Wolanski E, Asaeda T, Tanaka A, Deleersnijder E (1996) Three dimensional island wakes in the field, laboratory experiments and numerical models. Cont Shelf Res 16:1437-1452

Young JW, Blaber SJM (1986) Feeding ecology of three species of midwater fishes associated with the continental slope of eastern Tasmania, Australia. Mar Biol 93:147-156

Submitted: August 25, 1999; Accepted: March 28, 2000 Proofs received from author(s): August 29, 2000 